Original article

\title{
A method for multiple intra-ring demarcation of coniferous trees
}

\author{
Young-In (David) PARK*, Guillaume DALLAIRE, Hubert MORIN \\ Département des Sciences fondamentales, Université du Québec à Chicoutimi, 555 boulevard de l’Université, Saguenay, Québec, Canada
}

(Received 1 December 2004; accepted 28 September 2005)

\begin{abstract}
Earlywood (E) and latewood (L) are arbitrary concepts, by consequence, the E/L demarcation method is as well. The threshold method has been widely used in wood anatomy as well as wood density. Because of the presence of the intra-annual variation in tree-ring structure, however, the conventional threshold method needs adjustment in an objective and effective way. We suggest the analysis of the error zone method for this adjustment. The method was tested with 500 radial cell files of mature balsam fir, and showed its potential as an objective, robust and easily applicable adjustment tool.
\end{abstract}

multiple intra-ring demarcation / intra-ring variation / wall-lumen ratio / Mork's definition / wood anatomy

Résumé - Une méthode pour la démarcation intra-cerne multiple de conifère. Le bois initial et le bois final sont des concepts arbitraires, de même que leur démarcation. La méthode de seuil est appliquée généralement dans le domaine de l'anatomie et de la densité du bois. Mais, la méthode conventionnelle du seuil nécessite des ajustements parce qu'il y a des variations dans la structure du cerne. Nous suggérons la méthode de l'analyse de la zone d'erreur pour effectuer cet ajustement. La méthode suggérée a été vérifiée avec 500 files radiales de cellules de sapin baumier matures, et elle a démontré son potentiel comme un moyen objectif, robuste et facile à appliquer.

démarcation intra-cerne multiple / variation intra-cerne / ratio parois-lumen / définition de Mork / anatomie du bois

\section{INTRODUCTION}

Earlywood (E) and latewood (L) demarcation for conifers is generally based on the wall-lumen $(\mathrm{W} / \mathrm{L})$ relation of cells. Mork's definition has long been used in wood anatomy. Mork suggested the division of $E$ and $L$ into a fixed intra-ring position where the index value $(=2 \times$ double cell wall thickness/cell lumen) exceeds 1 ([9], see also [4]). Such a threshold principle has been also widely used in wood density, a well-known treering characteristic related to the $\mathrm{W} / \mathrm{L}$ relation of cells [12]. The index value and wood density generally increase exponentially from the beginning to the end of a tree ring [3, 5, 10, 12]. In an ideal case (Fig. 1A), the principle is easily applicable: a tree ring begins with $E$ cells and once the index (density) value exceeds the given threshold, then all xylem cells produced are L cells.

In reality, however, there is a substantial variation in the structure within tree ring, and it can, sometimes, be large enough to exceed the given threshold (Fig. 1B). A formation of a false ring [14] or a light ring [13] may be the most wellknown, extreme phenomenon of such cases. If the index value(s) exceeds the given threshold in a given intra-ring zone, a manual correction may be needed. However, a manual correction is costly in terms of time and labour, especially when handling large data sets, and it can also be another source of possible operating error. Furthermore, it is sometimes difficult to decide where the demarcation position is when the index val- ues oscillate just around the given threshold, especially for some coniferous species like Picea sp., Abies sp., since they have a relatively smooth $\mathrm{E} / \mathrm{L}$ transition.

There have been many suggestions and modifications for $\mathrm{E} / \mathrm{L}$ demarcation in both fields (e.g. [2, 7, 8, 11]). However, the aforementioned problems associated with application of the threshold principle have not been studied in detail [10]. An adjustment method is needed which is robust enough to deal with large intra-ring variation, and works in an effective and objective way which allows low time and labour expenditure, but effective and reproducible decision on the demarcation position. The mathematical approaches using the maximum inflexion point (derivates) $[1,6]$ can be one possibility for that purpose. They were, however, developed to put forward only one demarcation position within a tree ring.

We present here a different approach incorporating these intra-ring variations. It is not our intention to suggest a new method for E/L demarcation, but to adjust and refine the conventional threshold methods, e.g. Mork's definition. The specific objectives of this paper are (1) to introduce an error zone analysis method to deal with large intra-ring variation in an objective and effective way, (2) to examine if the proposed method handles the intra-ring variation correctly, and (3) to apply this method for multiple intra-ring demarcation to mature balsam fir.

* Corresponding author: parkbaum@yahoo.com 

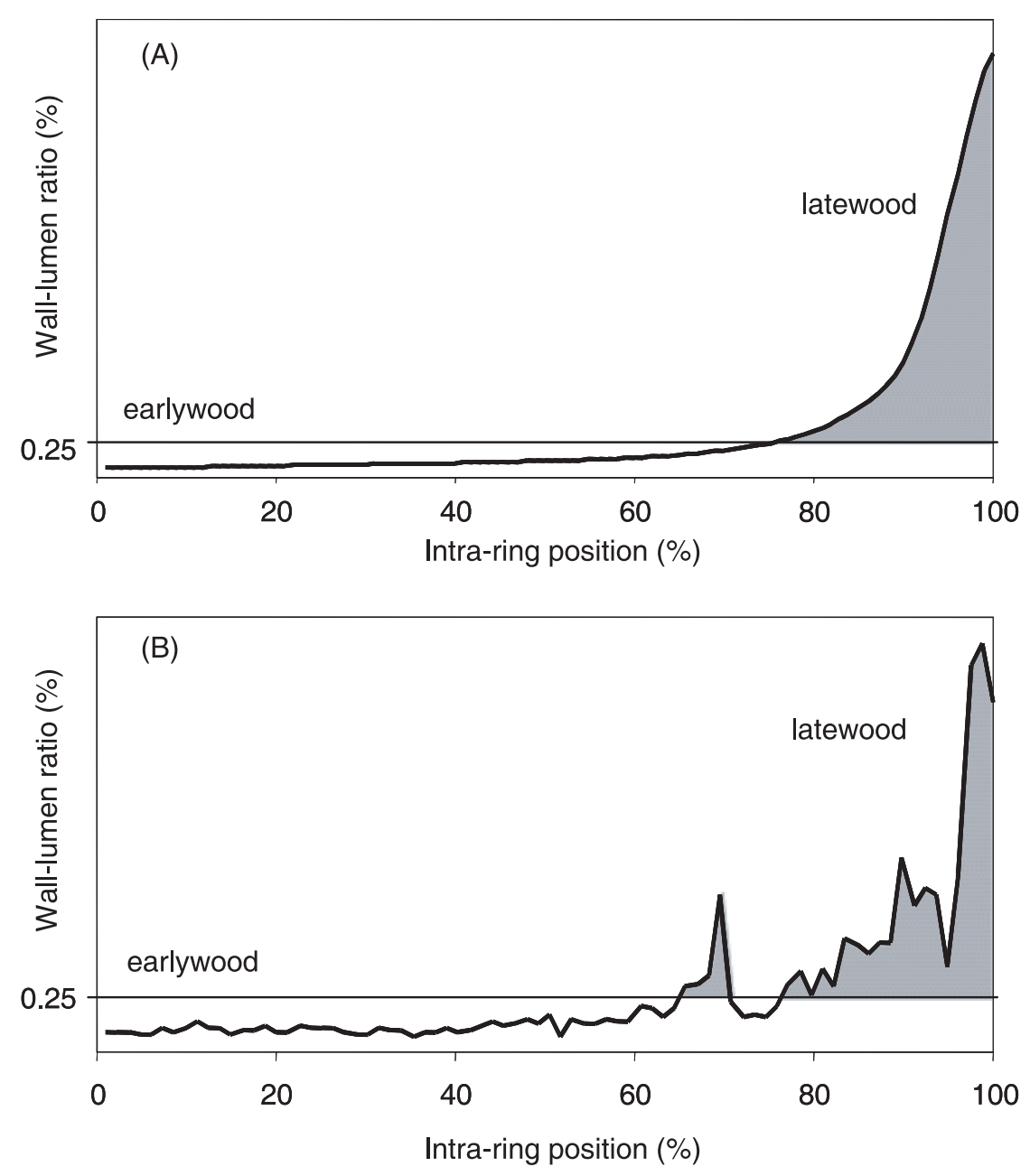

Figure 1. Intra-ring curve of wall-lumen ratio of tracheids. The mean curve of 500 radial cell files (A) and one example radial cell file (B) are presented. The horizontal line indicates the early-late wood boundary so that the grey marked area above the line indicates the identified latewood cells. The threshold 0.25 corresponds to the latewood definition by Mork (1928).

\section{CELL DATA}

Cell data were obtained from 20 mature balsam fir trees (on average 48 years old) growing naturally in Arvida $\left(48^{\circ} 26^{\prime} \mathrm{N}, 71^{\circ} 09^{\prime} \mathrm{W}, 80 \mathrm{~m}\right.$ a.s.l.), a district of Saguenay, Quebec, Canada. The annual mean air temperature of the site is $3.1{ }^{\circ} \mathrm{C}$, and total rainfall is $652 \mathrm{~mm}$. An additional $259.4 \mathrm{~mm}$ falls as snow annually. Sample trees have been subject to cambium monitoring since 1999 in the context of the project "Study on the spruce budworm epicenter in Arvida"; ten defoliated and ten control trees were sampled. Because there were no discernable differences in the intra-ring profiles of $\mathrm{W} / \mathrm{L}$ ratio between the groups, we did not separate data from the defoliation and control groups. Small wood samples were taken from the western side of each sample tree at $1.8 \mathrm{~m}$ height after the end of the 2000 growing season. Any discernable abnormalities, such as compression wood or false ring formation, were avoided. From each wood sample, transverse sections were obtained using a rotary microtome at $10 \mu \mathrm{m}$ and stained with $1 \%$ aqueous solution of safranin. Only the five most recently formed tree rings (1996-2000) were analyzed in order to make sure that no juvenile wood was involved. For each tree ring, five radial cell files with relatively large tracheids were measured using the image analysis system WinCELL [15]. These cells were not disturbed during development, e.g. by the emergence of resin ducts. The parameters obtained were cell number, cell diameter, lumen diameter, and single cell wall thickness. Intra-ring position was calculated relative to the cell number, so that the first cell of a radial cell file was set as the $1 \%$ and the last one as the $100 \%$ of intra-ring position. W/L ratio for each cell was calculated as the mean single cell wall thickness on both sides of each cell divided by its lumen diameter.

\section{ERROR ZONE ANALYSIS METHOD}

The method is based on the simple fact that cells are produced in a sequence from earlywood to latewood regardless of index value and not the inverse.

Therefore, when dividing a tree ring into $\mathrm{E}$ and $\mathrm{L}$ zones, the aim of this method will be to classify cells in a radial cell file which contains multiple $\mathrm{E}$ and $\mathrm{L}$ zones into only one earlywood and one latewood zone. Figure 2 illustrates an example with two artefacts (position 1 and 2) and one real latewood boundary (position 3 ). Before the selection process, a threshold for earlywood and latewood delimitation as well as a buffer value should be given. For the given example, a value of 0.25 is chosen as threshold corresponding to Mork's definition and 0.0125 for buffer zone, which is $1 / 20$ of the threshold. 


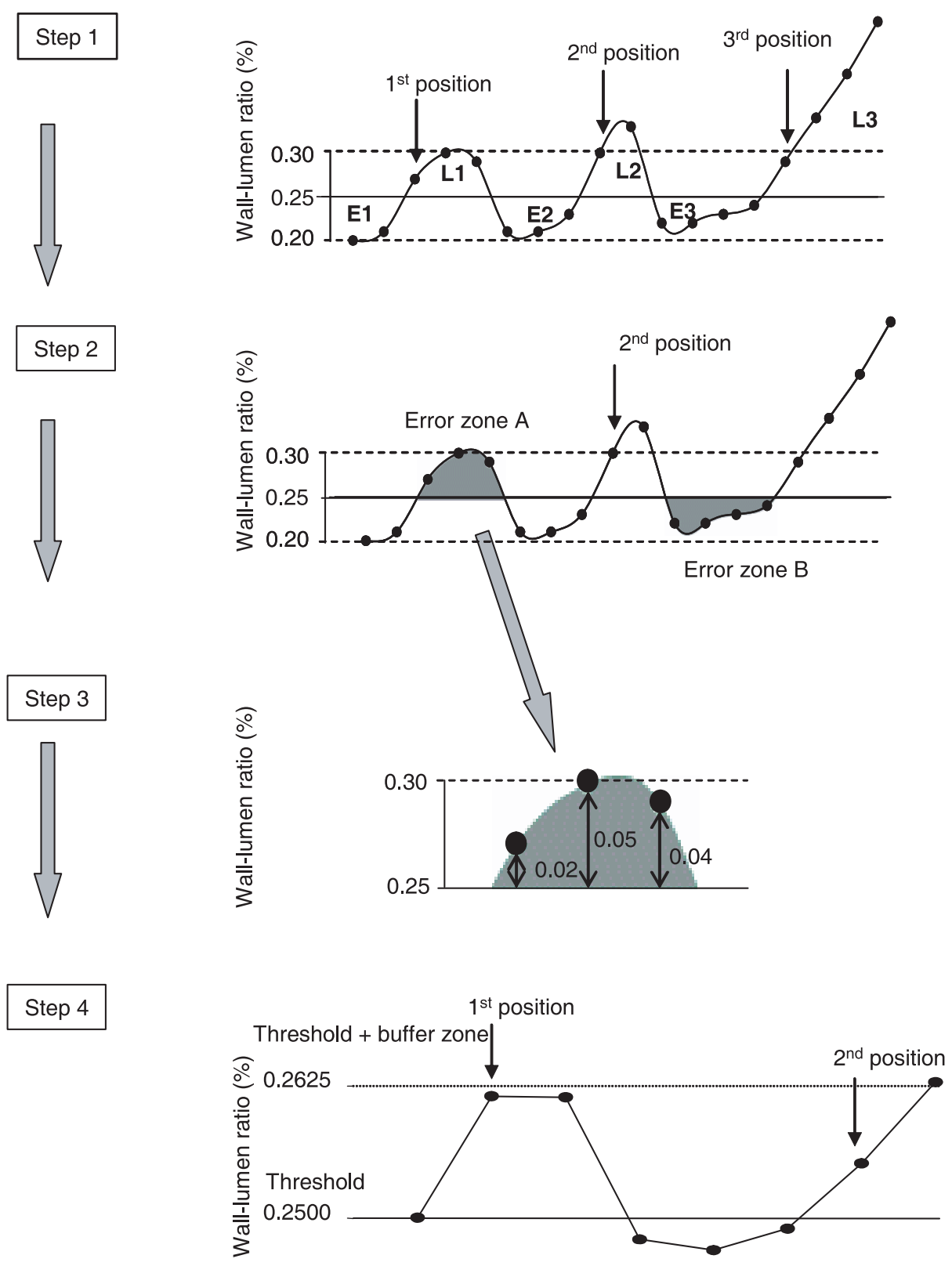

Figure 2. Schematic representation of the analysis of the error zone method for intra-ring demarcation. Presented is the wall-lumen (W/L) ratio of tracheids. The threshold 0.25 corresponds to the latewood definition by Mork (1928).

\subsection{Step 1: Identification of temporal demarcation positions}

Cells should first be classified into two different zones either as $\mathrm{E}$ or $\mathrm{L}$ zones depending on whether their values are over or below the given threshold (Fig. 2). The first cell in each L-zone is identified as a possible demarcation position. In the given example (Fig. 2, Step 1), three possible demarcation positions are identified: cell number 3 for position 1,9 for position 2 and 15 for position 3 , respectively.

\subsection{Step 2: Determination of error zones}

For each possible demarcation position, the associated error zones should be determined. The underlying idea is that there should be no
L cells before the true demarcation position. Likewise, there should be no E cells after the position. Therefore, all L cells before and all E cells after the demarcation position are "error" and each group of these cells generates the "error zone". In the given example (Fig. 2, Step 2), supposing the 2nd temporal demarcation position was true, then the group of L cells (marked as error zone A) in E-zone and a group of $\mathrm{E}$ cells (marked as error zone B) in L-zone will be the error zones. These two zones generate the error in association with the selection of the 2nd position.

\subsection{Step 3: Calculation of error factor}

The error factor is generated from the magnitude of divergence to the given threshold and the length of error zones identified. In the given 


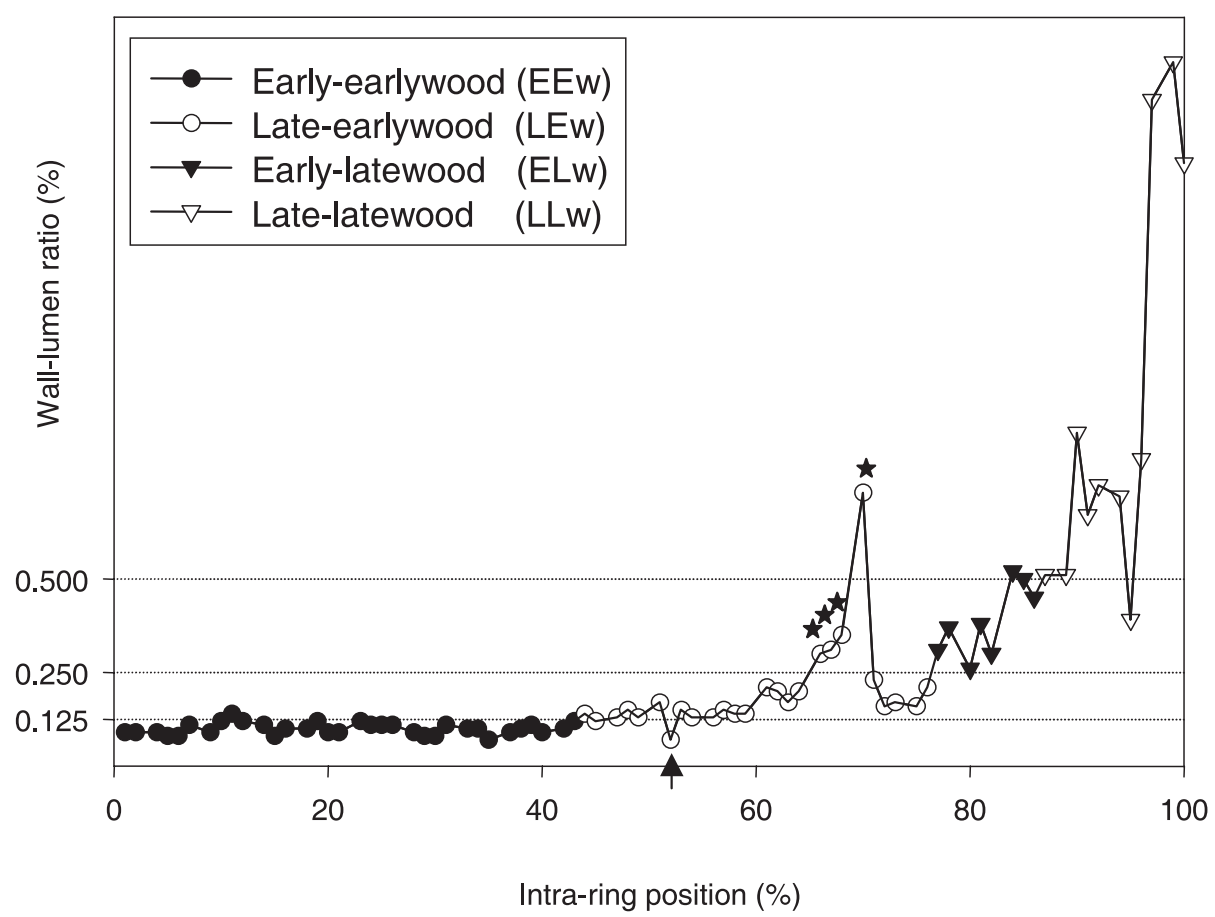

Figure 3. An example of multiple divisions within a tree ring. All tracheids in a radial cell file are classified into four different groups using the error zone analysis method. The given threshold of 0.25 corresponds to Mork's definition (1928) and each conventional earlywood and latewood zone is subdivided one more time. For threshold, the given threshold value of 0.25 is halved $(0.125)$ and doubled $(0.5)$ arbitrarily. The arrow and stars show the cells whose classification is changed with/without adjustment.

example (Fig. 2, step 3), error zone A consists of three cells which generate an error.

The magnitude of divergence of the error zone $\left(D_{\text {zone }}\right)$ is calculated as

$$
D_{\text {zone }}=\sum_{i=1}^{n} D(i)
$$

where $D(i)=$ absolute value of difference between the value of the selected cell and that of the threshold of ith cell.

Length of error zone $\left(\mathrm{L}_{\text {zone }}\right)$ is defined as

$$
\mathrm{L}_{\text {zone }}=\text { No. of cells in error zone. }
$$

The error factor for an error zone $\left(\mathrm{EF}_{\mathrm{zone}}\right)$ is defined as

$$
\mathrm{EF}_{\text {zone }}=\mathrm{L}_{\text {zone }}{ }^{3} \times D_{\text {zone }}
$$

where the exponential 3 gives more weight to the length of error zone than to the magnitude.

The choice of the exponential of 3 was empirical; it was chosen because the squares (exponential 2) did not deliver satisfactory results in the given data set. In case the individual cell variation is much larger, a higher order, e.g. exponential 4, is recommended.

The final error factor for the selected demarcation position $\left(\mathrm{EF}_{\text {position }}\right)$ is calculated as

$$
\mathrm{EF}_{\text {position }}=\mathrm{EF}_{\text {zone1 } 1}, \mathrm{EF}_{\text {zone2 }}, \ldots
$$

$\mathrm{EF}_{\text {position }}$ is calculated for each identified temporal position; then, the position with the lowest $\mathrm{EF}_{\text {position }}$ is selected as the real demarcation position, because $\mathrm{EF}_{\text {position }}$ will have the value of 0 in an ideal case (c.f. Fig. 1A).
For the given example in Figure 2 Step 1; if 1st position was selected, zone E2 and E3 will generate error. So,

$$
\begin{aligned}
\mathrm{EF}_{\text {position } 1}= & \mathrm{EF}_{\text {zone } \mathrm{E} 2}+\mathrm{EF}_{\text {zone } \mathrm{E} 3}=+3^{3} \times \sum_{i=3}^{5} D(i) \\
& +4^{3} \sum_{i=11}^{14} D(i)=3^{3} \times(0.04+0.04+0.02)+4^{3} \\
& \times(0.03+0.03+0.02+0.01)=2.70+5.76=8.46
\end{aligned}
$$

Likewise,

$$
\begin{aligned}
\mathrm{EF}_{\text {position2 } 2} & \mathrm{EF}_{\text {zone } \mathrm{L} 1}+\mathrm{EF}_{\text {zone } \mathrm{E} 3}=3^{3} \times(0.02+0.05+0.04) \\
& +4^{3} \times(0.03+0.03+0.02+0.01)=2.97+5.76=8.73 \\
\mathrm{EF}_{\text {position } 3=} & \mathrm{EF}_{\text {zone } \mathrm{L} 1}+\mathrm{EF}_{\text {zone } \mathrm{L} 2}=3^{3} \times(0.02+0.05 \\
& +0.04)+2^{3} \times(0.05+0.08)=2.97+1.04=3.08
\end{aligned}
$$

Position 3 has the lowest EF position value. Thus, the presented method chooses the real latewood boundary.

\subsection{Step 4. Application of buffer zone}

In some cases, the 2nd position in Figure 2 step 1 will be selected, which is considered incorrect according to the given definition (Fig. 3, step 4). This can happen when the error factor generated by zone B is smaller than the one generated by zone A, even when zone B is longer, although our method puts most of the weight into the zone length. This is because the $\mathrm{W} / \mathrm{L}$ ratio is inherently close to the given threshold value 

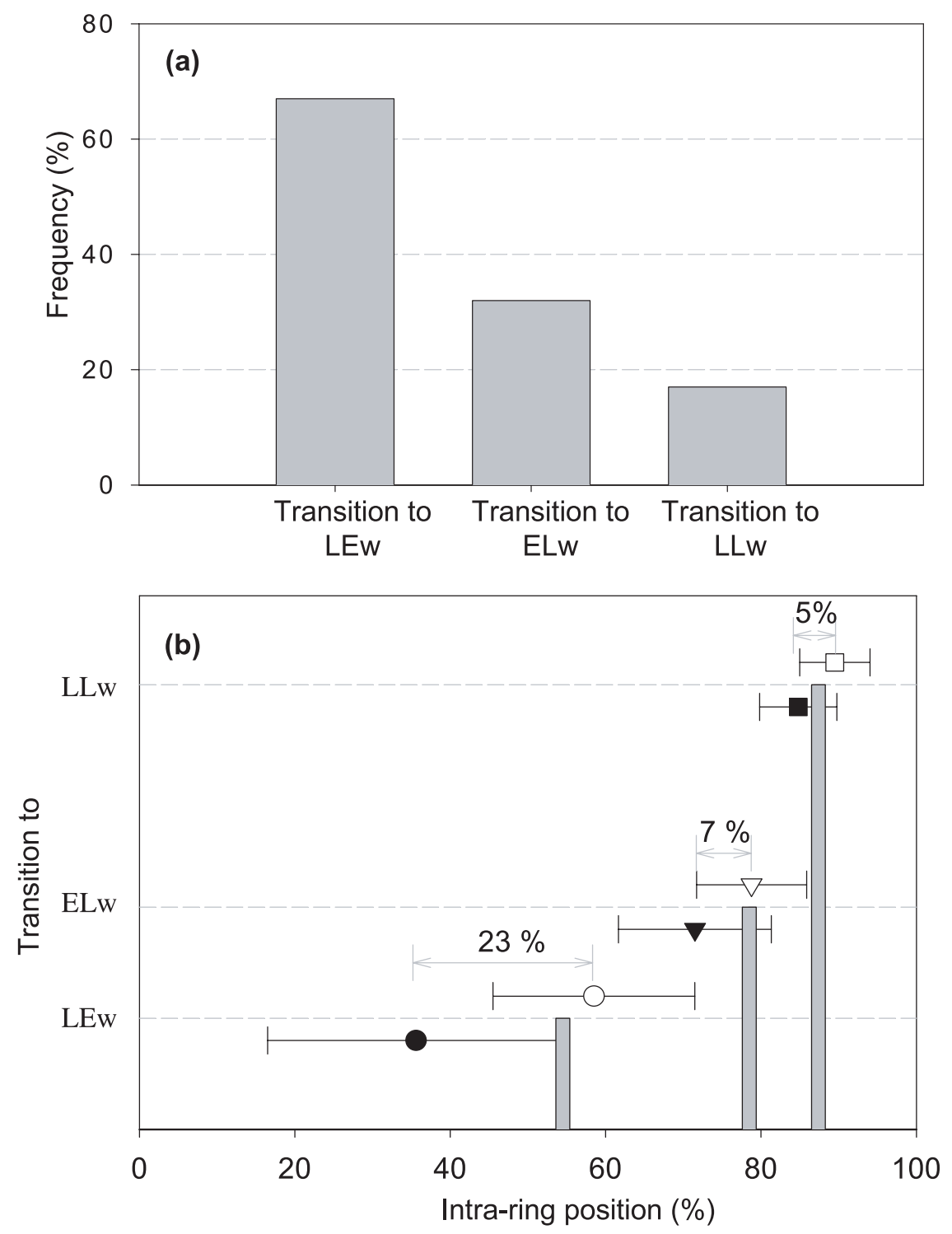

Figure 4. Frequency of problematic zone (a) and mean beginning position and its standard deviation (b) without (filled symbols) and with (empty symbols) adjustment. The mean position of transition to late-earlywood (LEw), early-latewood (ELw) and late-latewood (LLw) is marked with circle, triangle, and square, respectively. The vertical bars indicate the mean beginning position of each intra-ring zone of tree rings which contain no problematic zone. Y-axis is arbitrary and adjusted for better visualisation.

with increasing intra-ring position (c.f. Fig. 1A). For such a case, we apply a buffer zone. The buffer is a value added to the given threshold and defines an additive limit zone where certain variations can be ignored (Fig. 2, step 4). So, when the W/L ratio of a selected demarcation position does not exceed the buffer zone (threshold + buffer) and when the following zone is longer, then the demarcation position will shift to the next position (e.g. to 2nd position in Fig. 2, step 4). Otherwise, the first selected position will be accepted. The $1 / 20$ of the threshold value was found to be adequate $(0.25 / 20=0.0125)$ for the given data set. It can be adjusted depending on the data variance.

\section{EVALUATION OF THE METHOD FOR MULTIPLE INTRA-RING DEMARCATION}

The method was tested with an example data set modified slightly from the measured data of balsam fir in order to give an extreme intra-ring variation (Fig. 3). The given threshold of 0.25 in Figure 3 corresponds to Mork's definition and each of the conventional $\mathrm{E}$ and $\mathrm{L}$ zones are arbitrarily subdivided one more time by halving (0.125) and doubling (0.5) the given threshold value. For convenience, we called the subdivided zones Early-earlywood (EEw), Late-earlywood (LEw), Earlylatewood (ELw), and Late-latewood (LLw) in a sequence.

The W/L ratio increases exponentially towards the end of the cell file, as expected (c.f. Fig. 1A). However, as seen in Figure $1 \mathrm{~B}$, there are important variations. For instance, in LEw zone (corresponding to the conventional transition zone) in Figure 3, the 7th cell (marked by an arrow) is lower than the threshold. It should belong to the EEw zone in the narrow sense of the application, even though it was produced apparently later than these cells. More evidence can be found in the later part 
of the same zone. There are four cells (marked by a star) which exceed the threshold. When the conventional method is strictly applied, three of them should belong to the ELw zone, and even the last cell has the characteristic for the LLw zone. However, these cells are apparently produced before the real latewood cells. The result indicates that the analysis of error zone method is robust and reproducible, despite large intra-ring variation, and that it suits our visual judgement.

\section{MULTIPLE INTRA-RING DEMARCATION OF BALSAM FIR TREES}

We examined 500 radial cell files from the sample trees with an Excel macro developed in our laboratory. The macro was written in the WinCell [15] data format and it took just a few seconds for the adjustment of one Excel data file. Even though we selected "normal" tree rings without any visible structural abnormality, we observed a high frequency of problematic zones where the error zones were generated (Fig. 4a). The most problematic zones were found in the earlier intra-ring part, where the systematically increasing trend is not yet developed; e.g., some $66 \%$ of all cell files show at least one problematic zone in the transition to LEw. In these cell files, the transition was set at $36 \pm 1.1 \%$ of the intra-ring position without adjustment, but with adjustment, it was set about $23 \%$ later, at $59 \pm$ $0.7 \%$ (Fig. 4b). This reinforces the necessity of the adjustment, because in other cell files with no problematic zones, it took place at $55 \pm 1.1 \%$ (Fig. 4b). Once increasing tendency becomes evident, the differences reduce progressively, but about one-third of cell files studied still have problematic zones in the conventional transition to latewood (ELw in Fig. 4b). The existence of such an important proportion of problematic zones can imply a high probability of data contamination. In Figure 1b, for example, one would consider the year "normal", when cells were grouped without adjustment, and averaged for each group, since cells of $66 \sim 71 \%$ of relative position will be grouped as $\mathrm{L}$ because of their high ratio. In reality, these cells are apparently produced earlier then real L cells. After adjustment as presented in this paper, these cells will be grouped as E cells, when using only the conventional $\mathrm{E} / \mathrm{L}$ division, or more precisely as LEw cells in the four subdivisions (Fig. 3). It will result in an increase in mean value, indicating something happened during the formation of this part of the tree ring. If one can observe a similar pattern of $\mathrm{W} / \mathrm{L}$ ratio in most of the sampled trees, it may reflect some changes in growing conditions and provide valuable information on the environmental conditions affecting the formation of this part of the tree ring, such as early growing season precipitation [14].

\section{CONCLUSION}

Earlywood and latewood are arbitrary concepts, by consequence, the E/L demarcation method is as well. There have been various suggestions for $\mathrm{E} / \mathrm{L}$ demarcation. However, it is imperative that the method be objective and reproducible regardless which methods are applied. The presence of problematic zones in our data indicates that the conventional threshold method needs an adjustment; we suggest the analysis of error zones for that purpose. Because the analysis was conducted with more or less "normal" tree-rings, the practicability of the presented method should be tested with a variety of treering structures. In our data set and simulation, the error factor analysis worked robustly, objectively and in an easily reproducible way. In addition, with the possibility of adjusting the power and buffer value, it is very data-adaptable.

Acknowledgments: This study was financed by the Natural Sciences and Engineering Research Council of Canada and Consortium de recherché sur la forêt boréale commerciale.

\section{REFERENCES}

[1] Barbour R.J., Bergqvist G., Larsson B., Johnson J.A., New methods for evaluating intraring $X$-ray densitometry data: maximum derivative methods as compared to Mork's Index, in: Zhang S.Y., Gosselin R., Chauret G. (Eds.), Timber management toward wood quality and end product value; Proceedings of the CTIA/UFRO International wood quality workshop, August 18-22, Quebec City, Canada, 1997, pp. II-61-II-67.

[2] Creber G.T., Chaloner W.G., Environmental influences on cambial activity, in: Iqbal I. (Ed.), The vascular cambium, John Wiley \& Sons, New York, 1990, pp. 159-199.

[3] Decoux V., Varcin E., Leban J.-M., Relationships between the intra-ring wood density assessed by X-ray densitometry and optical anatomical measurements in conifers. Consequences for the cell wall apparent density determination, Ann. For. Sci. 61 (2004) 251-262.

[4] Denne M.P., Definition of latewood according to Mork (1928), IAWA Bull. 10 (1988) 59-62.

[5] Ivkovica M., Rozenberg P., A method for describing and modelling of within-ring wood density distribution in clones of three coniferous species, Ann. For. Sci. 61 (2004) 759-769.

[6] Koubaa A., Zhang S.Y., Makni S., Defining the transition from early wood to latewood in black spruce based on intra-ring wood density profiles from X-ray densitometry, Ann. For. Sci. 59 (2002) 511-518.

[7] Mellerowicz E.J., Coleman W.K., Riding R.T., Little C.H.A., Periodicity of cambial activity in Abies balsamea. 1. Effects of temperature and photoperiod on cambial dormancy and frost hardiness, Physiol. Plant. 85 (1992) 515-525.

[8] Mitchell M.D., Denne M.P., Variation in density of Picea sitchensis in relation to within-tree trends in tracheid diameter and wall thickness, Forestry 70 (1997) 47-60.

[9] Mork E., Die Qualität des Fichtenholzes unter besonderer Rücksichtnahme auf Schleif- und Papierholz, Der Papier-Fabrikant 48 (1928) 741-747.

[10] Park Y.I. Zur Auswirkung von Umwelteinflüssen auf das Wachstum von Fichten (Picea abies (L.) Karst.) auf der Grundlage bildanalytischer Verfahren zur Quantifizierung der Zellstruktur an Holzquerschnittsflächen, Schriftenreihe Freiburg Forstliche Forschung (FFF) Vol. 8, 2000.

[11] Savva Y., Schweingruber F.H., Milyutin L., Vaganov E.A., Genetic and environmental signals in tree rings from different provenances of Pinus sylvestris L. planted in the southern taiga, central Siberia, Trees 16 (2002) 313-324.

[12] Schweingruber F.H., Der Jahrring: Standort, Methodik, Zeit und Klima in der Dendrochronologie, Haupt, Bern, 1983.

[13] Wang L., Payette S., Bégin Y., Relationships between anatomical and densitometric characteristics of black spruce and summer temperature at tree line in northern Quebec, Can. J. For. Res. 32 (2002) $477-486$

[14] Wimmer R., Strumia G., Holawe F., Use of false rings in Austrian pine to reconstruct early growing season precipitation, Can. J. For. Res. 30 (2000) 1691-1697.

[15] WinCELL, version 2001a, Régent Instruments Inc., Quebec, Canada, 2001. 